\title{
当科における先天性内転足の治療について
}

九州大学医学部整形外科

$\begin{array}{llllll}\text { 内 } & \text { 芳 } & \text { 雄 }- \text { 野 村 茂 治 } \\ \text { 近 藤 } & \text { 正 一 一佐 伯 } & \text { 満 } \\ \text { 前 川 正 幸: } & & & \end{array}$

\section{Our Treatment for Congenital Metatarsus Varus}

by

\author{
Y. Uchida, S. Nomura, M. Kondo, M. Saeki, \\ and M. Maekawa. \\ Department of Orthopedic Surgery, Faculty of \\ Medicine, Kyushu University.
}

\begin{abstract}
Congenital metatarsus varus is different from congenital club foot in many respects, but thy have been often confused.

We experienced eight cases of this deformity during the years 1970 through 1979 which is sufficiently severe to require treatment in corrective casts. Two were unilateral and six were bilateral.

Here we discuss the diagnosis and results of treatment in our clinic.
\end{abstract}

\section{はじめに}

先天性内転足は, 内反足と全く異なる変形にもかか わらず，内反足としばしば混同され，治療されている 場合が少なくない. この変形は, 1933 年に Peabody \& Muro が詳細に報告して以来, 種々の報告が散見 されるが，世間一般の認識度は低い。かが国では， 1968 年に土屋らの報告をみるにすぎない.

当科では, 昭和 45 年以来 8 例 13 足の先天性内転足 を経験したので，文献的考察を加え報告する.

\section{臨 床 的 特 徵}

先天性内転足は, 次の臨床的特徽をもつ.

(1) 足関節の運動制限がなく尖足要因がない.

(2) 前足部の内転, 時に内反がみられる.

(3) 踵骨の内反がない.

(4) 距骨頭の外方扁位がない.

(5) 第 5 中足骨基部を中心として外方凸の変形を示 す.

臨床的に内反足と最も大きく異なる点は, 尖足要因
がないということである. また内反足では, 踵骨が脂 肪におおわれてふれにくいのに対し, 内転足では, 容 易にふれることができる. 治療後, 内反足では, 足長 が短縮し, 腓腹筋の萎縮がみられることが多いのに対 し，内転足では，乙れがみられない。

レントゲンでは, 第 1 図の如く, 内反足と異なる所 見を有する. 前後像では, talocalcaneal angle は,

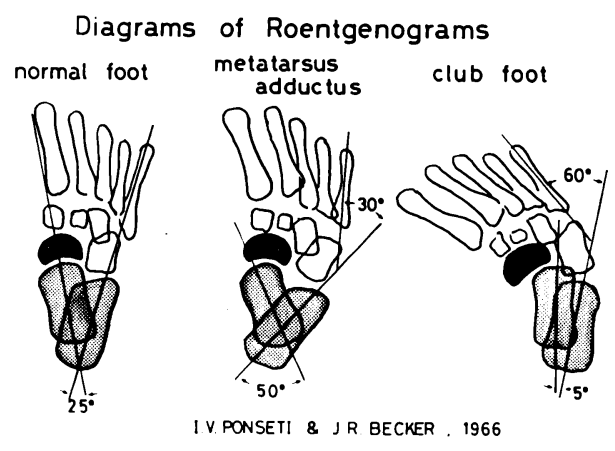

第1図内転足では, 内反足と違い, talo-calcaneal angle は, 正常加増大. また舟状 骨は, 距骨頭の外方に扁位する。 
表 1 症

例

\begin{tabular}{|c|c|c|c|c|c|c|c|}
\hline 症 & 例 & 性 別 & 初診時年令 & 左: 右 & ギプス治療 & 合 併 奇 形 & 追 跡期 間 \\
\hline $\begin{array}{l}1 . \\
2 . \\
3 . \\
4 . \\
5 . \\
6 . \\
7 . \\
8 .\end{array}$ & & $\begin{array}{l}\text { 女 } \\
\text { 男 } \\
\text { 男 } \\
\text { 女 } \\
\text { 男 } \\
\text { 男 } \\
\text { 女 } \\
\text { 女 }\end{array}$ & $\begin{array}{c}17 \text { 日 } \\
1 \text { 招出 } \\
15 \text { 日 } \\
3 \text { 日 } \\
9 \text { 日 } \\
8 \text { 日 } \\
15 \text { 日 } \\
1 \text { 力月 }\end{array}$ & 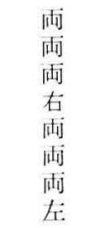 & $\begin{array}{c}1 \text { 力月 } \\
5 \text { 力月 } \\
1.5 \text { 力月 } \\
2 \text { 力月 } \\
4 \text { 力月 } \\
4 \text { 力月 } \\
1 \text { 力月 } \\
2 \text { 力月 }\end{array}$ & 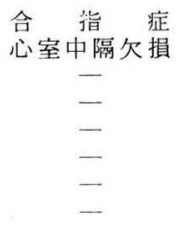 & $\begin{array}{l}3 \text { 力月 } \\
6 \text { 力月 } \\
7 \text { 力月 } \\
1 \text { 年 } \\
1 \text { 年 } \\
2 \text { 年. } \\
\text { 6年. }\end{array}$ \\
\hline
\end{tabular}

内反足では減少するのに対し, 内転足では正常か, ま たは少し増大する．また，舟状骨は，距骨の外方に扁 位する. 中足骨の内転は, 通常第 1 中足骨で最も大で ある.

$$
\text { 対象 }
$$

当科で昭和 45 年以来経験した 8 例， 13 足を対象と した（表 1).なお，今回の対象には，前足部がかた く，外転時に抵抗を示すもののみをいれた. 内訳は， 男 3 例, 女 5 例, 片側例 2 例, 両側例 6 例である. 追 跡期間は, 最短 2 力月, 最長 6 年である. 遺伝傾向を 示すものはなく，2 例に他の合併奇形がみられた.

\section{治療方 法}

全例 cast にて治療. cast は, 内反足の cast と は, 多くの点で異なり, 注意を要する. まず, 踵をし っかりと中間位，または軽度内反位に保持し，立方骨 を支点として，左手で第 1 中足骨をもって外転する。

(第 2 図).
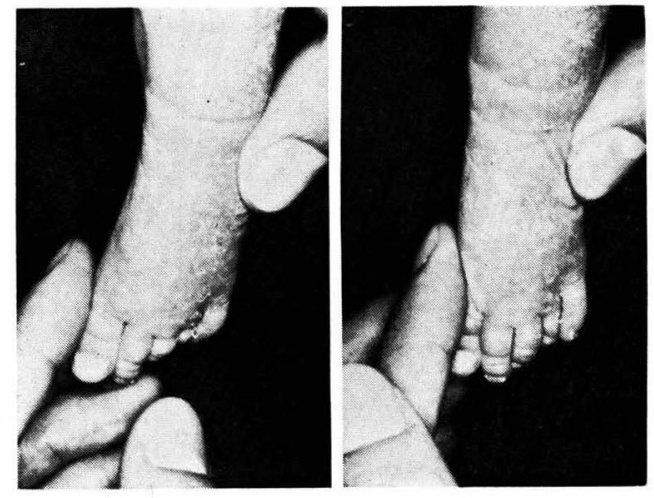

第2図矯正方法

踵を中間位又は，軽度内反位に保持し，立方骨 を支点として，第 1 中足骨をもって外転する.
この時, 前足部は特に回内・回外することなく, 後 足部の状態にあわせて，そのまま外転する．内反足の 治療の時のように後足部を外反させてはいけない. 将 来, 重度の外反扁平足を発生させるおそれがあるから である.

cast は, 生後数力月以内の乳児では, 大腿からの cast を原則とし, 年長児では, 歩行を許可するため に膝下としている.

臨床的に前足部が正中線をこえて外転できるように なれば，夜間装具また，年長児では，靴型装具へと移 行している.

結

果

臨床的に 8 例中, 6 例は容易に前足部の内転が矯正 され，現在までのととろ再発はないが，2 例は難治例 で, 長期間の corrective cast を要し, 再発傾向を 示した.

レ線評価法としてわれわれは, 第 3 図の如く, 前 後, 左右像における talo-calcaneal angle 及び, 前 後像における first metatarso-calcaneal angle を

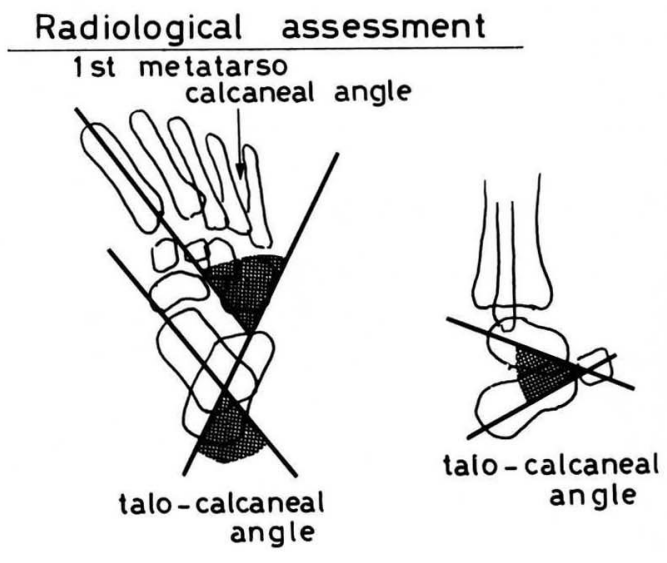

第3図レ線評価法 
計測し，治療前と治療後を比較してみた。 その結果， 前後及び左右像における talo-calcaneal angle は, 治療後わずかに減少, first metatarso-calcaneal angle は，著明な減少を示した（第 4 図 (a),(b)). 中足骨における内転は，通常第 1 中足骨で最む大な ので，われわれは，レ線による評価としては, first metatarso-calcaneal angle が最も適切だと考え る. 症例を供覧する.

\section{〈症例 1〉}

生後 1 力月 女
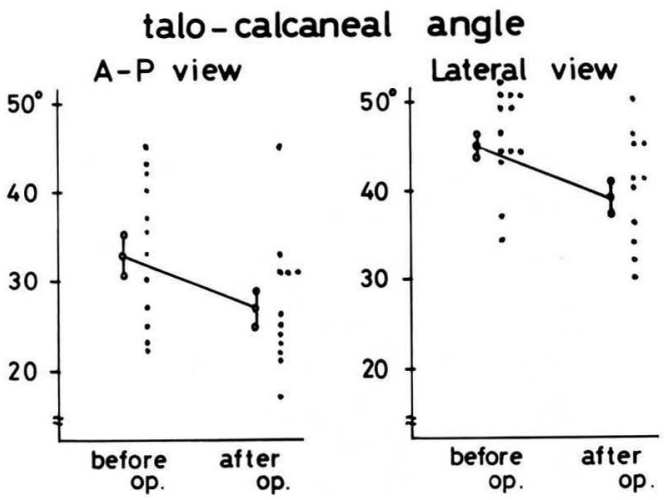

第4図（a）前後及び左右像における talocalcaneal angleは治療後わずかに減少

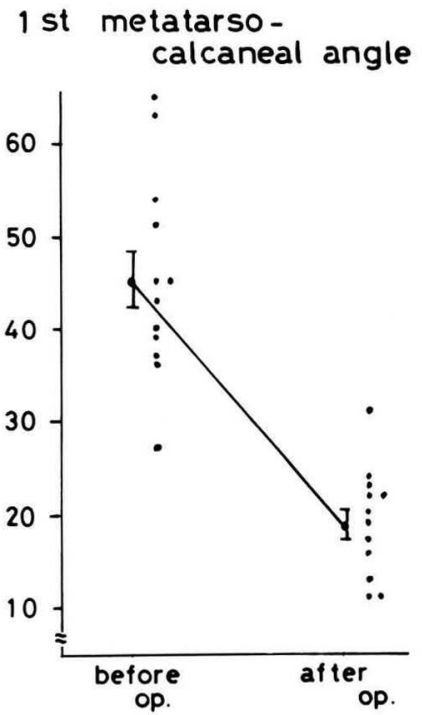

第4 図（b） First metatarso-calcaneal angle は治㜣後著明に減少

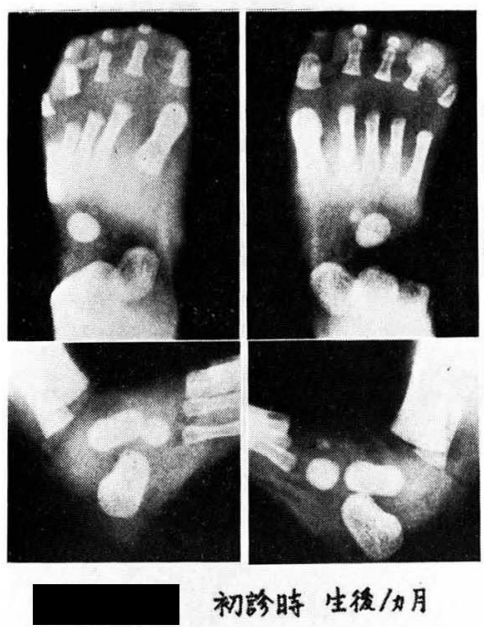

第 5 図（a）症例 1

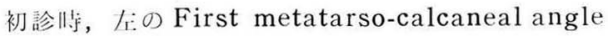

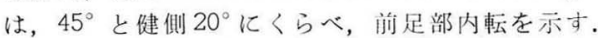
右像における talo calcaneal angle は桜常て ある。

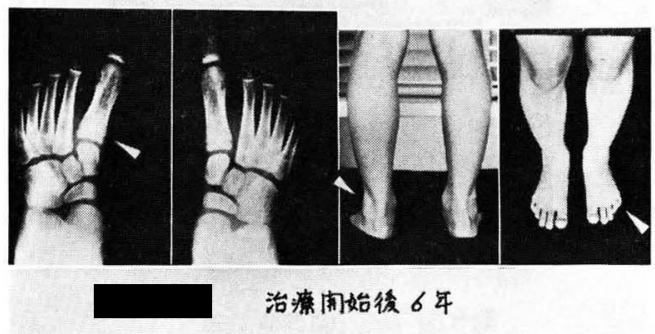

第 5 図（b）治弪開始後6年 First metatarso calcaneal angle 足長短檞もない.

生後 3 週にて左前足部の内転に匃付く。初㟝時, 左 の first metatarso-calcaneal angle は, $45^{\circ}$ と健 側 $20^{\circ}$ にくらべ, 内転を示す. 左右像における talocalcaneal angle は, 正常である（第 5 図 (a)). 2 力月間 corrective cast ののち, 7 力月間装具. 6 年後, 再発はみられず, 足部の筋萎縮及び, 足長の短 縮はみられない(第 5 図 (b)).

\section{〈症例 2 〉}

1 才 3 力月 男

生直後より丹親が両足部变形に父付く. 生後 6 力月 


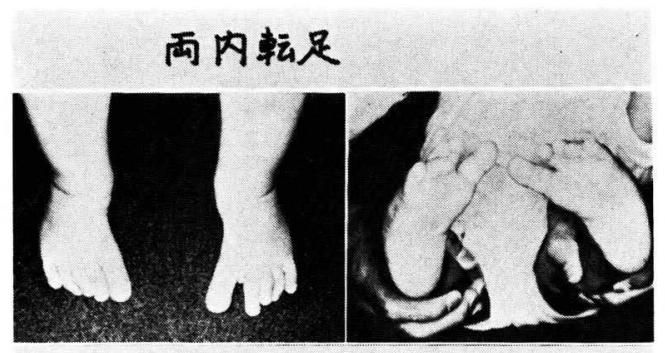

初站時 / メふ力月

第 6 図 (a) 症例 2

初診時, 強い前足部内転を示し, 们足变形を呈す.

\section{両内転足}

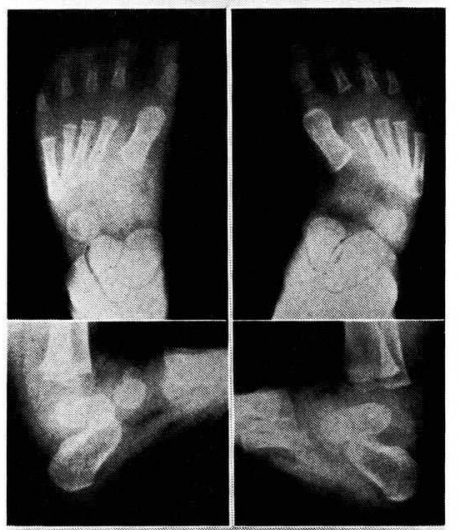

初教時 /

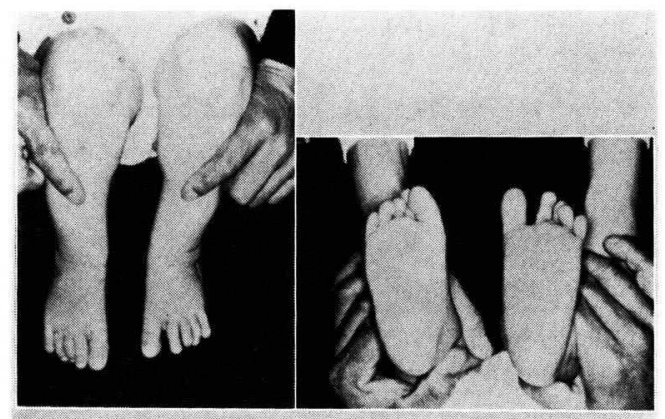

治療闻始淩5力月

第6図（c）治療開始後 5 力月 前足部内転はみられない。

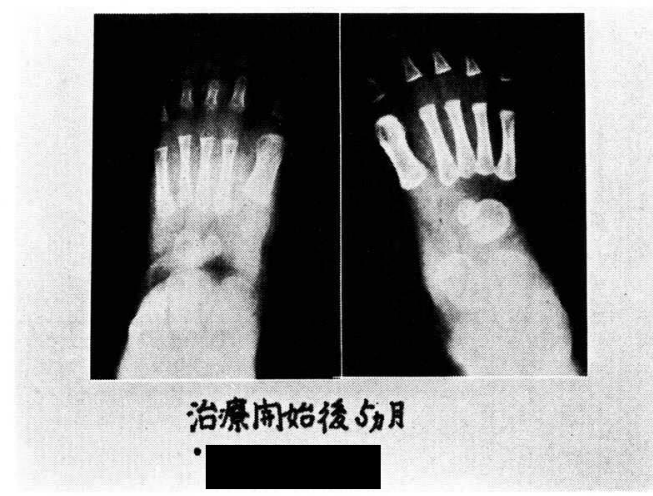

第6図 (d) First metatarsocalcaneal angle は, 右 $16^{\circ}$ 左: $13^{\circ}$ と改善している.

考察

先天性内転足は，一般になおりやすい疾患とされ， 放置して打いてかまわないという意見も多い. しか し，前足部を他動的に外転させる時にかたく抵抗を示 すむのは, 将来, 外反母趾を発生させるおそれもあ り, 治療の必要があろう.

治療には, corrective cast が最適で, 両親による 不完全な manipulation は，さけた方がよい，治療 は,われわれの経験からしても，早期に開始するほど 容易で，短期間ですむようである．矯正にあたって は，踵骨外反をきたさないよう充分な注意が必要であ ๖.

Kite は，先天性内転足の成因には，脛骨筋群之腓 骨筇群の筋力不均衡が大きく関与していると強調して いるが，これのみならず，Thomsonが述べている如 
く，母趾外転筋等の関与も考えられる.

現在，先天性内転足に対するはっきりした診断基準 はなく，主として診察者の主観にたよるとてろが大き い．また呼び名も報告者により，まちまちである，早 急に㟝断基準を確立することが必要であろう.

\section{結語}

当科における内転足の治療について報告した．内転 足の治療上の注意として

(1) 内転足の治療にあたっては，その解剖学的関係 を熟知しておくことが必要である.

(2) 踵骨外反をきたさないように治療すること.

(3) 少数の難治例があり再発傾向が強い.

\section{文献}

1) Peabody, C. W., and Muro, F.: Congenital Metatarsus Varus. J. Bone Joint surg., 15: 171-189, 1933.

2) Kite, J. H.: Congenital Metatarsus Varus. Report of 300 cases. J. Bone and Joint Surg., 32: A 500-506, 1950.

3) McCauley, J. Jr., Lusskin, R. and Bromley, J.: Recurrence in Congenital Metatarsus Varus. J. Bone Joint Surg., 46-A : 525532, 1964.

4) Ponseti, I. V., and Becker, J. R.: Congenital Metatarsus Adductus. The Re- sults of Treatment. J. Bone Joint Surg., 48-A : 702-711, 1966

5) Kite, J. H.: Congenital Metatarsus Varus, J. Bone Joint Surg., 49-A : 388-397, 1967.

6) Rushforth, G. F.: The natural history of hooked forefoot. J. Bone and Joint Surg., 60-B : 530-532, 1978.

7) Thomson, S. A.: Hallux Varus and Metatarsus Varus. A Five-year study (19541958) Clin. Orthop., 16: 109-118, 1960.

8）土屋弘吉・他：先天性中足骨内反について。臨 佅整形外科。第 3 巻, 554-565。 1968.

罂問長崎大 鈴木 良平

診断基準をうかがいたい. Metatarso-calcaneal angle が何度ぐらいから本症ときめるべきか？

回答整形 内田 芳雄

現在症例数も少なく，はっきりした診断基準はたて てないが，臨床的に前足部がかたく内転を示し，他動 的に外転する時に抵抗を示すすの，及びレ線的には， first metatarso-calcaneal angle が $40^{\circ}$ 程度以上 のあのを診断の目安としている.

左右像に打ける talo-calcaneal angle が正常か, または少し增大しているということが，軽い内反足と の鑑別上重要である. 